\title{
Pengaruh Kompetensi Sumber Daya Manusia, Sistem Pengendalian Intern Pemerintah, Pemahaman Basis Akrual, dan Pemanfaatan Teknologi Informasi terhadap Kualitas (Studi Kasus pada OPD Kabupaten Tegal)
}

\author{
Akuntansi \\ Alfi Aulia ${ }^{1)}$, Budi Susetyo ${ }^{2)}$, Teguh Budi Raharjo ${ }^{3)}$ \\ Fakultas Ekonomi dan Bisnis, Universitas Pancasakti Tegal \\ alfiaulia6@gmail.com, uset23brahayoe@yahoo.co.id, teguhbudir00@gmail.com
}

\begin{abstract}
The research aims to determine the competency of human resources, internal government control system, understanding of the accrual base and utilization of information technology affecting the quality of financial report of the District government Tegal. This research is conducted on Regional device Organization (OPD) of Tegal district. The type of data used is primary data, with the number of respondents as much as 92 people. Data collection methods are performed with questionnaires. While the data analysis method used is a double linear regression analysis using SPSS program version 22. The results of this study show that, human resource competence affects a significant value of 0.004, the internal control system is influential in the significant value of 0.035, the understanding accrual base is influential with a significant value of 0.000, Utilization of information technology affects the significant value of 0.003. The result of coefficient of determination test was obtained by 0.663 or $66.3 \%$. It can be interpreted that $66.3 \%$ the quality of the regional government's financial statements in this model is influenced by human resources competency, Government internal control system, understanding of the accrual base and utilization of information technology. The remaining $33.7 \%$ is influenced by other factors outside of this research model.
\end{abstract}

Keywords: competency of human resources, government internal control system, understanding of the accrual base, utilization of information technology, financial statements of local government

\begin{abstract}
Abstrak
Penelitian ini bertujuan untuk mengetahui kompetensi sumber daya manusia, sistem pengendalian internal pemerintah, pemahaman basis akrual dan pemanfaatan teknologi informasi berpengaruh terhadap kualitas laporan keuangan pemerintah daerah Kabupaten Tegal. Penelitian ini dilakukan pada Organisasi Perangkat Daerah (OPD) Kabupaten Tegal. Jenis data yang digunakan adalah data primer, dengan jumlah responden sebanyak 92 orang. Metode pengumpulan data dilakukan dengan kuesioner. Sedangkan metode analisis data yang digunakan adalah analisis regresi linier berganda dengan menggunakan program SPSS versi 22. Hasil penelitian ini menunjukkan bahwa, kompetensi sumber daya manusia berpengaruh pada nilai signifikan 0,004, sistem pengendalian internal berpengaruh pada nilai signifikan 0,035, pemahaman basis akrual berpengaruh dengan nilai signifikan 0,000, pemanfaatan teknologi informasi berpengaruh pada nilai signifikan 0,003. Hasil uji koefisien determinasi diperoleh $R^{2}$ sebesar 0,663 atau 66,3\%. Dapat diartikan bahwa 66,3\% kualitas laporan keuangan pemerintah daerah dalam model ini dipengaruhi oleh kompetensi SDM, sistem pengendalian internal pemerintah, pemahaman basis akrual dan pemanfaatan teknologi informasi. Sedangkan sisanya sebesar 33,7\% dipengaruhi oleh faktor lain diluar model penelitian ini.
\end{abstract}




\section{Kata Kunci: Kompetensi Sumber Daya Manusia, Sistem Pengendalian Internal Pemerintah, Pemahaman Basis Akrual, Pemanfaatan Teknologi Informasi, Laporan Keuangan Pemerintah Daerah}

\section{Pendahuluan}

Perkembangan akuntansi sektor publik di Indonesia semakin pesat yang ditandai dengan adanya Era Reformasi dalam pelaksanaan kebijakan pemerintahan, Otonomi Daerah dan Desentralisasi Fiskal yang menitik beratkan pada Pemerintah Daerah (Juwita, 2013). Akuntansi sektor publik mencakup alat informasi baik bagi pemerintah sebagai manajemen maupun alat informasi bagi publik (Mardiasmo, 2009: 14). Akuntansi sektor publik sendiri telah mengalami perkembangan yang sangat pesat, saat ini praktik akuntansi yang dilakukan oleh pemerintah khususnya pemerintah daerah mendapat perhatian lebih dari masyarakat, terdapat tuntutan besar untuk dilakukan transparansi dan akuntabilitas publik oleh pemerintah daerah. Salah satu upaya konkret untuk mewujudkan transparansi dan akuntabilitas tersebut yakni menyampaikan laporan pertanggungjawaban berupa Laporan Keuangan Pemerintah Daerah (Saputra, 2015).

Pemerintah merupakan salah satu entitas publik yang harus mempertanggungjawabkan kinerjanya dalam bentuk laporan keuangan. Pengelolaan keuangan disusun sesuai peraturan perundang-undangan, efisien, efektif, serta transparan merupakan kewajiban dari suatu entitas pemerintah. Sebagai salah satu bentuk pertanggungjawaban dalam penyelenggaraan pemerintah yang diatur dalam Undang-undang Nomor 17 Tahun 2003 tentang Keuangan Negara dan Undang-undang Nomor 23 Tahun 2004 tentang Pemerintah Daerah, upaya konkrit dalam mewujudkan transparansi dan akuntabilitas dalam pengelolaan keuangan pemerintah dengan cara melaporkan laporan pertanggungjawaban berupa laporan keuangan (Yosefrinaldi, 2013). Hasil temuan pemeriksaan BPK atas 542 (100\%) LKPD tahun 2017, mengungkapkan opini Wajar Tanpa Pengecualian (WTP) atas 411 (76\%) LKPD, opini Wajar Dengan Pengecualian (WDP) atas 113 (21\%) LKPD, dan opini Tidak Menyatakan Pendapat (TMP) atas 18 (3\%) LKPD. Pada kenyataannya dari seluruh LKPD, yang belum mendapatkan opini Wajar Tanpa Pengecualian (WTP) itu masih terdapat kelemahan dalam penyusunan laporan keuangan.
Hal itu dikarenakan banyak penyajian laporan keuangan yang tidak sesuai dengan prinsip-prinsip akuntansi yang berlaku umum. Sementara itu, sejak tahun 2002 sampai 2015 laporan keuangan Pemerintah Kabupaten Tegal selalu mendapat opini Wajar Dengan Pengecualian (WDP) dan sekali saja di tahun 2008 Disclaimer, dimana auditor BPK menolak memberikan pendapat. Menurut Bupati Tegal Enthus Susmono, salah satu aspek yang menjadi ganjalan selama ini adalah dalam pengelolaan aset tetap milik pemerintah daerah. Dari temuan BPK soal keberadaan asset tersebut sebesar Rp. 49.000.000.000.berhasil ditelusuri dan ditindak lanjuti hingga tersisa Rp. 6.000.000.000.- saja yang akan dikejar penuntasannya, terutama keberadaan asset tanah, Bapak Enthus Susmono mengaku proses penelusuran asset tersebut tidaklah mudah, karena masalah tersebut muncul sejak puluhan tahun yang lalu atau sebelum sistem pengendalian internal berjalan dengan baik. Dikutip dari berita online (setda.tegalkab.go.id). Hal ini menunjukkan bahwa selama empat belas tahun pengelolaan keuangan di Kabupaten Tegal tidak memenuhi prinsip akuntansi yang berlaku umum sehingga mempengaruhi kualitas laporan keuangan tersebut.

Secara empiris penelitian mengenai faktor-faktor yang mempengaruhi kualitas laporan keuangan pemerintah daerah telah sering dilakukan antara lain oleh Karsana \& Suaryana (2017), Andrianto (2017) Kiranawati \& Erawati (2016) dan Rahmadani (2015).

Berdasarkan latar belakang yang telah diuraikan di atas, penulis mencoba merumuskan masalah penelitian sebagai berikut :

1. Apakah terdapat pengaruh Kompetensi Sumber Daya Manusia (SDM) terhadap kualitas Laporan Keuangan Pemerintah Daerah (LKPD) di OPD Kabupaten Tegal?

2. Apakah terdapat pengaruh Sistem Pengendalian Internal Pemerintah terhadap kualitas Laporan Keuangan Pemerintah Daerah (LKPD) di OPD Kabupaten Tegal?

3. Apakah terdapat pengaruh Pemahaman Basis Akrual terhadap kualitas Laporan Keuangan Pemerintah Daerah (LKPD) di 
OPD Kabupaten Tegal?

4. Apakah terdapat pengaruh Pemanfaatan Teknologi Informasi (TI) terhadap kualitas Laporan Keuangan Pemerintah Daerah (LKPD) di OPD Kabupaten Tegal?

\section{Kerangka Pemikiran}

2.1. Pengaruh Kompetensi Sumber Daya Manusia Terhadap Kualitas Laporan Keuangan Pemerintah Daerah

Dalam bukunya meldona (2009:15) menyatakan Sumber Daya Manusia diartikan sebagai "sumber" dari kekuatan yang berasal dari manusia-manusia yang dapat didayagunakan oleh organisasi. Kompetensi sumber daya manusia yang memadai dalam hal kuantitas dan kualitas akan meningkatkan nilai informasi dalam pelaporan keuangan pemerintahan. Hasil penelitian ini sejalan dengan penelitian terdahulu yang dilakukan oleh Karsana \& Suaryana (2017), Tut Madiguna Agung \& Gayatri (2018), dan Ade Saputra (2015) yang membuktikan dimana Kompetensi Sumber Daya Manusia (SDM) memiliki pengaruh terhadap laporan keuangan. Hal ini membuktikan bahwa apabila pegawai memiliki tanggungjawab dan menjalankan tugasnya berdasarkan pedoman maka kompetensinya semakin baik dan semakin baik pula kualitas laporan keuangan pemerintah daerah.

H1 : Kompetensi Sumber Daya Manusia berpengaruh Terhadap Kualitas Laporan Keuangan Pemerintah Daerah

\subsection{Pengaruh Sistem Pengendalian Intern Pemerintah berpengaruh Terhadap Kualitas Laporan Keuangan Pemerintah Daerah}

Menurut Pemendagri No. 13 Tahun 2006 tentang Pedoman Pengelolaan Keuangan Daerah, pengertian Sistem Pengendalian Intern Pemerintah merupakan proses yang dirancang untuk memberikan keyakinan yang memadai mengenai pencapaian tujuan pemerintah daerah yang tercermin dari keunggulan laporan keuangan, efisiensi dan efektivitas pelaksanaan program dan kegiatan serta dipatuhinya peraturan perundang-undangan. Hal ini menunjukan bahwa adanya penerapan sistem Pengendalian Internal yang baik, maka kualitas Laporan Keuangan Pemerintah Daerah Kabupaten Tegal akan semakin membaik. Semakin tinggi tingkat penerapan Sistem Pengendalian Internal maka akan semakin tinggi pula tingkat Kualitas Laporan Keuangan Pemerintah daerah, begitupun sebaliknya, semakin rendah sistem pengendalian internal maka semakin rendah tingkat kualitaslaporan keuangan pemerintah daerah. Hasil penelitian ini sejalan dengan hasil penelitian yang sudah dilakukan oleh Andrianto (2017) dan Ida Ayu Enny Kiranayanti, \&Ni Made Adi Erawati (2016) menyatakan bahwa Sistem Pengendalian Intern Pemerintah memiliki pengaruh terhadap kualitas laporan keuangan. Hal ini membuktikan bahwa apabila pimpinan menerapkan sistem pengendalian internal dilakukan dengan baik disetiap OPD Maka akan meningkatkan kualitas laporan keuangan pemerintah daerah.

H2 : Sistem Pengendalian Intern Pemerintah berpengaruh Terhadap Kualitas Laporan Keuangan Pemerintah Daerah

\subsection{Pengaruh Pemahaman Basis Akrual Terhadap Kualitas Laporan Keuangan Pemerintah Daerah \\ Semakin tinggi tingkat Pemahaman} Basis Akrual maka kualitas laporan keuangan pemerintah daerah Kabupaten Tegal akan semakin tinggi. Begitu pula sebaliknya semakin rendah tingkat Pemahaman Basis Akrual maka kualitas laporan keuangan pemerintah daerah Kabupaten Tegal akan semakin rendah. Hasil penelitian ini sejalan dengan hasil penelitian yang sudah dilakukan oleh Kiranawati \& Erawati (2016) menyatakan bahwa Pemahaman Basis Akrual memiliki pengaruh terhadap Kualitas Laporan Keuangan Pemerintah Daerah. Pemahaman disini yaitu pemahaman regulasi dari PP NO.71 Tahun 2010. Jika SAP dapat diterapkan dengan baik dan selalu dipakai acuan dalam penyusunan laporan keuangan maka pemerintah daerah akan memiliki kualitas informasi laporan keuangan yang baik dan benar. Dengan terciptanya laporan keuangan yang baik dan benar maka akan terwujud 
pemerintahan yang bersih dan berwibawa. H3 : Pemahaman Basis Akrual berpengaruh Terhadap Kualitas Laporan Keuangan Pemerintah Daerah

\subsection{Pengaruh Pemanfaatan Teknologi Informasi Terhadap Kualitas Laporan Keuangan Pemerintah Daerah \\ Pemerintah daerah berkewajiban} untuk mengembangkan dan memanfaatkan kemajuan teknologi informasi untuk meningkatkan kemampuan mengelola keuangan daerah, dan menyalurkan informasi keuangan daerah kepada pelayanan publik (Peraturan Pemerintah No. 65 tahun 2010). Jika teknologi dimanfaatkan secara maksimal maka kualitas laporan keuangan pemerintah daerah semakin baik. Hasil penelitian ini sejalan dengan hasil penelitian yang sudah dilakukan oleh Dicky Rahman dan Suci Rahmadani (2015), Elvin Andrianto (2017) dan Tut Madiguna Agung \& Gayatri (2018) yang menyatakan bahwa teknologi informasi berpengaruh terhadap kualitas laporan keuangan pemerintah daerah. Hal ini berarti penggunaan komputer dan memanfaatkan jaringan internet dapat meningkatkan kualitas laporan keuangan pemerintah daerah. Semakin baik pemanfaatn teknologi informasi, maka semakin baik pula kualitas laporan keuangan pemerintah daerah yang dihasilkan.

H4 : Pemahaman Basis Akrual berpengaruh Terhadap Kualitas Laporan Keuangan Pemerintah Daerah

\section{Metode Penelitian}

Dalam pelaksanaan penelitian ini dilakukan menggunakan metode deskriptif kuantitatif. Sampel penelitian ini adalah 92 responden. Populasi berjumlah sebanyak 92 responden yang terdiri dari kepala dan staff keuangan di OPD Kab Tegal.

\section{Hasil dan Pembahasan}

Berdasarkan hasil data yang dikumpulkan dengan metode pengumpulan data peroleh deskripsi data tentang variabel penelitian seperti pada tabel berikut :

\subsection{Statisik Deskriptif}

Tabel 4.1

Hasil Analisis Statistik Deskriptif

\begin{tabular}{|l|c|c|c|c|c|}
\hline \multicolumn{7}{|c|}{ Descriptive Statistics } & $\begin{array}{c}\text { Std. } \\
\text { Deviation }\end{array}$ \\
\hline $\begin{array}{l}\text { Laporan Keuangan } \\
\text { Pemerintah Daerah }\end{array}$ & 92 & 41 & 55 & 47,36 & 3,557 \\
\hline $\begin{array}{l}\text { Sumber Daya } \\
\text { Manusia }\end{array}$ & 92 & 40 & 65 & 52,47 & 5,113 \\
\hline $\begin{array}{l}\text { Sistem Pengendalian } \\
\text { Intern Pemerintah }\end{array}$ & 92 & 45 & 68 & 56,51 & 4,918 \\
\hline $\begin{array}{l}\text { Pemahaman Berbasis } \\
\text { Akrual }\end{array}$ & 92 & 83 & 120 & 99,89 & 8,219 \\
\hline Teknologi Informasi & 92 & 22 & 35 & 30,74 & 3,137 \\
\hline Valid N (listwise) & 92 & & & & \\
\hline
\end{tabular}

Sumber : Data sekunder diolah

Tabel diatas menunjukkan statistik deskriptif dari variabel-variabel yang diteliti. Variabel kompetensi Sumber Daya Manusia memiliki nilai minimum sebesar 40 , nilai maksimum sebesar 65 , rata-rata sebesar 52,47 dan standar deviasi sebesar 5,113. Variabel Sistem Pengendalian Intern Pemerintah (SPIP) memiliki nilai minimum sebesar 45 , nilai maksimum sebesar 68, rata-rata sebesar 56,51 dan standar deviasi sebesar 4,918. Variabel Pemahaman Basis Akrual memiliki nilai minimum sebesar 83, nilai maksimum sebesar 120, rata-rata sebesar 99,89 dan standar deviasi sebesar 8,219. Variabel Teknologi Informasi memiliki nilai minimum sebesar 22, nilai maksimum sebesar 35 , rata-rata sebesar 
30,74 dan standar deviasi sebesar 3,137.

Variabel Kualitas Laporan Keuangan

Pemerintah Daerah memiliki nilai minimum

\subsection{Uji Validitas}

sebesar 41, nilai maksimum sebesar 55, ratarata sebesar 47,36 dan standar deviasi sebesar 3,557 .

Tabel 4.2

Hasil Uji Validitas

\begin{tabular}{|c|c|c|c|c|}
\hline Variabel & $\begin{array}{l}\text { Kode } \\
\text { Item }\end{array}$ & r Hitung & r Tabel & Keterangan \\
\hline \multirow{11}{*}{$\begin{array}{c}\text { Kualitas } \\
\text { Laporan } \\
\text { Keuangan } \\
\text { Pemerintah } \\
\text { Daerah (Y) }\end{array}$} & y11 & 0,348 & 0,1726 & Valid \\
\hline & y12 & 0,313 & 0,1726 & Valid \\
\hline & y13 & 0,477 & 0,1726 & Valid \\
\hline & y14 & 0,448 & 0,1726 & Valid \\
\hline & y15 & 0,418 & 0,1726 & Valid \\
\hline & y16 & 0,600 & 0,1726 & Valid \\
\hline & y17 & 0,480 & 0,1726 & Valid \\
\hline & y18 & 0,495 & 0,1726 & Valid \\
\hline & y19 & 0,482 & 0,1726 & Valid \\
\hline & y110 & 0,467 & 0,1726 & Valid \\
\hline & y111 & 0,472 & 0,1726 & Valid \\
\hline \multirow{13}{*}{$\begin{array}{l}\text { Sumber Daya } \\
\text { Manusia (X1) }\end{array}$} & $\mathrm{x} 11$ & 0,315 & 0,1726 & Valid \\
\hline & $\mathrm{x} 12$ & 0,409 & 0,1726 & Valid \\
\hline & $\mathrm{x} 13$ & 0,356 & 0,1726 & Valid \\
\hline & $\mathrm{x} 14$ & 0,289 & 0,1726 & Valid \\
\hline & $\mathrm{x} 15$ & 0,597 & 0,1726 & Valid \\
\hline & $\mathrm{x} 16$ & 0,581 & 0,1726 & Valid \\
\hline & $\mathrm{x} 17$ & 0,668 & 0,1726 & Valid \\
\hline & x18 & 0,647 & 0,1726 & Valid \\
\hline & $\mathrm{x} 19$ & 0,670 & 0,1726 & Valid \\
\hline & $\mathrm{x} 10$ & 0,616 & 0,1726 & Valid \\
\hline & $\mathrm{x} 111$ & 0,621 & 0,1726 & Valid \\
\hline & x112 & 0,638 & 0,1726 & Valid \\
\hline & x113 & 0,511 & 0,1726 & Valid \\
\hline \multirow{8}{*}{$\begin{array}{c}\text { Sistem } \\
\text { Pengendalian } \\
\text { Internal (X2) }\end{array}$} & $\mathrm{x} 21$ & 0,384 & 0,1726 & Valid \\
\hline & $\mathrm{x} 22$ & 0,427 & 0,1726 & Valid \\
\hline & $\mathrm{x} 23$ & 0,529 & 0,1726 & Valid \\
\hline & $\mathrm{x} 24$ & 0,630 & 0,1726 & Valid \\
\hline & $\mathrm{x} 25$ & 0,369 & 0,1726 & Valid \\
\hline & $\mathrm{x} 26$ & 0,472 & 0,1726 & Valid \\
\hline & $\mathrm{x} 27$ & 0,637 & 0,1726 & Valid \\
\hline & x28 & 0,607 & 0,1726 & Valid \\
\hline
\end{tabular}




\begin{tabular}{|c|c|c|c|c|}
\hline & $\mathrm{x} 29$ & 0,672 & 0,1726 & Valid \\
\hline & $\mathrm{x} 210$ & 0,580 & 0,1726 & Valid \\
\hline & $\mathrm{x} 211$ & 0,738 & 0,1726 & Valid \\
\hline & $\mathrm{x} 212$ & 0,536 & 0,1726 & Valid \\
\hline & $\mathrm{x} 213$ & 0,623 & 0,1726 & Valid \\
\hline & $\mathrm{x} 214$ & 0,461 & 0,1726 & Valid \\
\hline \multirow{24}{*}{$\begin{array}{c}\text { Pemahaman } \\
\text { Berbasis } \\
\text { Akrual } \\
\text { (X3) }\end{array}$} & $\mathrm{x} 31$ & 0,181 & 0,1726 & Valid \\
\hline & $\mathrm{x} 32$ & 0,190 & 0,1726 & Valid \\
\hline & $\mathrm{x} 33$ & 0,198 & 0,1726 & Valid \\
\hline & x34 & 0,363 & 0,1726 & Valid \\
\hline & $\mathrm{x} 35$ & 0,384 & 0,1726 & Valid \\
\hline & x36 & 0,505 & 0,1726 & Valid \\
\hline & $\mathrm{x} 37$ & 0,449 & 0,1726 & Valid \\
\hline & x38 & 0,409 & 0,1726 & Valid \\
\hline & x39 & 0,558 & 0,1726 & Valid \\
\hline & $\mathrm{x} 310$ & 0,478 & 0,1726 & Valid \\
\hline & x311 & 0,478 & 0,1726 & Valid \\
\hline & x312 & 0,571 & 0,1726 & Valid \\
\hline & $\mathrm{x} 313$ & 0,681 & 0,1726 & Valid \\
\hline & x314 & 0,680 & 0,1726 & Valid \\
\hline & $\mathrm{x} 315$ & 0,668 & 0,1726 & Valid \\
\hline & $\mathrm{x} 316$ & 0,702 & 0,1726 & Valid \\
\hline & x317 & 0,665 & 0,1726 & Valid \\
\hline & x318 & 0,632 & 0,1726 & Valid \\
\hline & x319 & 0,659 & 0,1726 & Valid \\
\hline & $\mathrm{x} 320$ & 0,568 & 0,1726 & Valid \\
\hline & $\mathrm{x} 321$ & 0,529 & 0,1726 & Valid \\
\hline & $\mathrm{x} 322$ & 0,452 & 0,1726 & Valid \\
\hline & $\mathrm{x} 323$ & 0,546 & 0,1726 & Valid \\
\hline & x324 & 0,273 & 0,1726 & Valid \\
\hline \multirow{7}{*}{$\begin{array}{l}\text { Teknologi } \\
\text { Informasi } \\
\quad(\mathrm{X} 4)\end{array}$} & $\mathrm{x} 41$ & 0,535 & 0,1726 & Valid \\
\hline & $\mathrm{x} 42$ & 0,682 & 0,1726 & Valid \\
\hline & $\mathrm{x} 43$ & 0,770 & 0,1726 & Valid \\
\hline & $\mathrm{x} 44$ & 0,809 & 0,1726 & Valid \\
\hline & $\mathrm{x} 45$ & 0,783 & 0,1726 & Valid \\
\hline & $\times 46$ & 0,631 & 0,1726 & Valid \\
\hline & $\mathrm{x} 47$ & 0,531 & 0,1726 & Valid \\
\hline
\end{tabular}

Sumber : Olah Data SPSS Versi 22 


\subsection{Hasil Uji Reliabilitas}

Tabel 4.7

Hasil Uji Reliabilitas

\begin{tabular}{|l|c|c|c|}
\hline \multicolumn{1}{|c|}{ Variabel } & r Hitung & $\begin{array}{c}\text { Nilai Cronbach } \\
\text { Alpha }\end{array}$ & Status \\
\hline $\begin{array}{l}\text { Kualitas Laporan } \\
\text { Keuangan } \\
\text { Pemerintah Daerah }\end{array}$ & 0,709 & 0,7 & Reliabel \\
\hline Kompetensi SDM & 0,716 & 0,7 & Reliabel \\
\hline $\begin{array}{l}\text { Sistem Pengendalian } \\
\text { Intern Pemerintah }\end{array}$ & 0,801 & 0,7 & Reliabel \\
\hline $\begin{array}{l}\text { Pemahaman Berbasis } \\
\text { Akrual }\end{array}$ & 0,742 & 0,7 & Reliabel \\
\hline Teknologi Informasi & 0,771 & 0,7 & Reliabel \\
\hline
\end{tabular}

Sumber : Olah Data SPSS Versi 22

Dari hasil perhitungan uji reliabilitas, variabel Kompetensi Sumber Daya Manusia $\left(\mathrm{X}_{1}\right)$, Sistem Pengendalian Intern Pemerintah $\left(\mathrm{X}_{2}\right)$, Pemahaman Berbasis Akrual $\left(\mathrm{X}_{3}\right)$, Pemanfaatan Teknologi Informasi $\left(\mathrm{X}_{4}\right)$ dan Kualitas Laporan Keuangan Pemerintah Daerah (Y) diperoleh nilai reliabilitas lebih- besar bila dibandingkan nilai cronbach alpha yaitu 0,7. Artinya instrumen variabel Kompetensi Sumber Daya Manusia $\left(\mathrm{X}_{1}\right)$, Sistem Pengendalian Intern Pemerintah $\left(\mathrm{X}_{2}\right)$, Pemahaman Berbasis Akrual $\left(\mathrm{X}_{3}\right)$, Pemanfaatan Teknologi Informasi $\left(\mathrm{X}_{4}\right)$ dan Kualitas Laporan Keuangan Pemerintah Daerah (Y) dinyatakan reliabel.

\subsection{Uji Normalitas}

Tabel 4.8

Hasil Uji Normalitas (Uji Statistik)

\begin{tabular}{|c|c|c|}
\hline \multicolumn{3}{|c|}{ One-Sample Kolmogorov-Smirnov Test } \\
\hline & & $\begin{array}{l}\text { Unstandardized } \\
\text { Residual }\end{array}$ \\
\hline \multicolumn{2}{|l|}{$\mathrm{N}$} & 92 \\
\hline \multirow[t]{2}{*}{ Normal Parameters } & Mean &, 0000000 \\
\hline & Std. Deviation & 2,02023486 \\
\hline \multirow[t]{3}{*}{ Most Extreme Differences } & Absolute & ,064 \\
\hline & Positive &, 064 \\
\hline & Negative &,- 032 \\
\hline \multicolumn{2}{|l|}{ Test Statistic } &, 064 \\
\hline \multicolumn{2}{|l|}{ Asymp. Sig. (2-tailed) } & $200^{\mathrm{c}, \mathrm{d}}$ \\
\hline \multicolumn{3}{|l|}{ a. Test distribution is Normal. } \\
\hline \multicolumn{3}{|l|}{ b. Calculated from data. } \\
\hline \multicolumn{3}{|c|}{ c. Lilliefors Significance Correction. } \\
\hline
\end{tabular}

Sumber: Output SPSS Versi 22

Berdasarkan hasil output pengolahan data uji normalitas dengan menggunakan rumus Kolmogorov-Smirnov Test sebagaimana tertera pada tabel 4.8, maka dapat diperoleh nilai Asymp. Sig. (2-tailed) sebesar 0,200 lebih besar dari 0,05. Sehingga dapat disimpulkan bahwa data yang diuji berdistribusi normal. 


\subsection{Uji Multikolonieritas}

Tabel 4.5

Coefficients $^{\mathrm{a}}$

Hasil Uji Multikolonieritas

\begin{tabular}{|l|l|r|r|}
\hline \multirow{2}{*}{ Model } & \multicolumn{2}{|c|}{ Collinearity Statistics } \\
\cline { 3 - 4 } & & Tolerance & \multicolumn{1}{c|}{ VIF } \\
\hline 1 & (Constant) &, 566 & 1,765 \\
\cline { 2 - 4 } & Sumber Daya Manusia &, 854 & 1,171 \\
\cline { 2 - 4 } & $\begin{array}{l}\text { Sistem Pengendalian } \\
\text { Internal Pemerintah }\end{array}$ &, 518 & 1,931 \\
\cline { 2 - 4 } & $\begin{array}{l}\text { Pemahaman Berbasis } \\
\text { Akrual }\end{array}$ &, 703 & 1,423 \\
\cline { 2 - 4 } & Teknologi Informasi & \multicolumn{3}{|l}{} \\
\hline \multicolumn{2}{|l|}{ a. Dependent Variable: Laporan Keuangan Pemerintah Daerah } \\
\hline
\end{tabular}

Sumber: Output SPSS Versi 22

Berdasarkan hasil output uji multikolonieritas pada model regresi seperti tertera pada tabel 4.9, diperoleh data bahwa nilai tolerance Kompetensi SDM sebesar 0,566, Sistem Pengendalian Intern Pemerintah sebesar 0,854, Pemahaman Basis Akrual 0,518 dan Teknologi Informasi sebesar 0,703. Semua nilai tolerance tersebut masing-masing biaya > 0,1 . Sementara nilai dari VIF Kompetensi

SDM sebesar 1,765, Sistem Pengenalian Internal Pemerintah sebesar 1,171, Pemahaman Basis Akrual 1,931 dan Teknologi Informasi sebesar 1,423. Semua nilai VIF tersebut masing-masing $<10,00$. Sehingga dapat diperoleh suatu kesimpulan bahwa model regresi dalam penelitian ini tidak terjadi gejala multikolonieritas.

\subsection{Uji Auto Korelasi}

Tabel 4.6

Hasil Uji Autokorelasi

\begin{tabular}{|l|c|r|r|r|c|}
\hline \multicolumn{7}{|c|}{ Model Summary $^{\mathbf{b}}$} \\
\hline Model & $\mathrm{R}$ & R Square & $\begin{array}{c}\text { Adjusted R } \\
\text { Square }\end{array}$ & $\begin{array}{l}\text { Std. Error of } \\
\text { the Estimate }\end{array}$ & $\begin{array}{l}\text { Durbin- } \\
\text { Watson }\end{array}$ \\
\hline 1 &, $823^{\mathrm{a}}$ &, 677 &, 663 & 2,066 & 1,260 \\
\hline
\end{tabular}

a. Predictors: (Constant), Teknologi Informasi, Sistem Pengendalian Internal Pemerintah, Sumber Daya Manusia, Pemahaman Berbasis Akrual b. Dependent Variable: Laporan Keuangan Pemerintah Daerah Sumber : Output SPSS Versi 22

Berdasarkan data tabel 4.10 diperoleh nilai hitung Durbin-Watson sebesar 1,260, hal ini menunjukkan bahwa nilai tersebut lebih besar dari -2 dan lebih kecil dari 2 atau $-2<1,260<2$. Maka dapat disimpulkan, data yang digunakan dalam penelitian ini bebas auokorelasi atau tidak terjadi autokorelasi. 


\subsection{Analisis Linier Berganda}

Tabel 4.11

Hasil Analisis Regresi Berganda

\begin{tabular}{|c|c|c|c|c|c|c|}
\hline \multicolumn{7}{|c|}{ Coefficients $^{\mathrm{a}}$} \\
\hline & & \multicolumn{2}{|c|}{$\begin{array}{l}\text { Unstandardized } \\
\text { Coefficients }\end{array}$} & \multirow{2}{*}{$\begin{array}{c}\begin{array}{c}\text { Standardized } \\
\text { Coefficients }\end{array} \\
\text { Beta }\end{array}$} & \multirow[b]{2}{*}{$\mathrm{T}$} & \multirow[b]{2}{*}{ Sig. } \\
\hline \multicolumn{2}{|c|}{ Model } & $\mathrm{B}$ & Std. Error & & & \\
\hline \multirow[t]{5}{*}{1} & (Constant) & 6,185 & 3,250 & & 1,903 &, 060 \\
\hline & $\begin{array}{l}\text { Sumber Daya } \\
\text { Manusia }\end{array}$ &, 164 & ,056 & ,236 & 2,919 & ,004 \\
\hline & $\begin{array}{l}\text { Sistem } \\
\text { Pengendalian } \\
\text { Internal } \\
\text { Pemerintah }\end{array}$ &, 102 & ,048 & ,141 & 2,139 &, 035 \\
\hline & $\begin{array}{l}\text { Pemahaman } \\
\text { Berbasis Akrual }\end{array}$ &, 190 & ,037 & ,439 & 5,193 & , 000 \\
\hline & $\begin{array}{l}\text { Teknologi } \\
\text { Informasi }\end{array}$ & ,254 & ,082 &, 224 & 3,080 & ,003 \\
\hline
\end{tabular}

Sumber: Output SPSS Versi 22

Pada kolom unstandardized coefficient (B), tertera nilai constant sebesar 6,185, koefisisen Kompetensi SDM sebesar 0,164, Sistem Pengendalian Internal Pemerintah sebesar 0,102, Pemahaman Basis Akrual 0,190, dan koefisien Teknologi Informasi sebesar 0,254.

Dengan demikian dapat ditulis persamaan regresi menjadi bentuk persamaan sebagai berikut:

$$
\mathrm{Y}=6,185+0,164 \mathrm{X} 1+0,102 \mathrm{X} 2+
$$$$
\text { 0,190X3+0,254X4+e }
$$

Persamaan tersebut mempunyai arti sebagai berikut:

a. Konstanta sebesar 6,185 berarti bahwa tanpa adanya variabel, Kompetensi SDM, Sistem Pegendalian Internal Pemerintah, Pemahaman Basis Akrual dan Teknologi Informasi, maka Kualitas Laporan
Keuangan Pemerintah daerah adalah sebesar 6,185

b. Jika variabel Kompetensi SDM naik satusatuan, maka akan menyebabkan kenaikan sebesar 0,164 pada Kualitas Laporan Keuangan Pemerintah Daerah.

c. Jika variabel Sistem Pengendalian Intern Pemerintah naik satu-satuan, maka akan menyebabkan kenaikan sebesar 0,102 pada Kualitas Laporan Keuangan Pemerintah Daerah.

d. Jika variabel Pemahaman Basis Akrual naik satu-satuan, maka akan menyebabkan kenaikan sebesar 0,190 pada Kualitas Laporan Keuangan Pemerintah Daerah.

e. Jika variabel Pemanfaatan Teknologi Informasi naik satu-satuan, maka akan menyebabkan kenaikan sebesar 0,254 pada Kualitas Laporan Keuangan Pemerintah Daerah. 


\subsection{Uji Statistik $t$}

Tabel 4.13

Hasil Uji Statistik t (Uji Parsial)

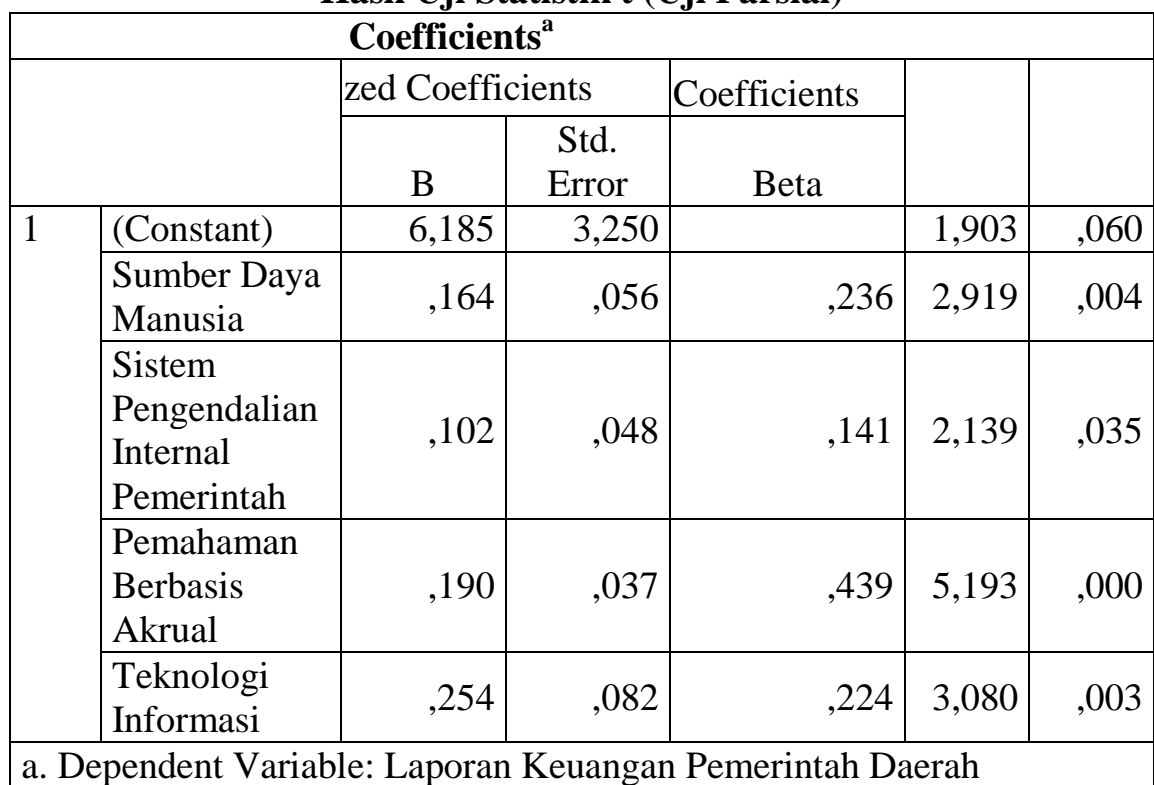

Sumber: Output SPSS Versi 22

Berdasarkan data yang terdapat dalam tabel 4.12 diperoleh suatu kesimpulan sebagai berikut:

1) Nilai signifikan $\mathrm{t}$ kompetensi sumber daya $\left(\mathrm{X}_{1}\right)$ sebesar0,04 sehingga nilai signifikan lebih kecil dari 0,05. Dengan demikian dapat disimpulkan bahwa kompetensi sumber daya manusia berpengaruh terhadap kualitas laporan keuangan pemerintah daerah di OPD Kabupaten Tegal.

2) Nilai signifikan $t$ sistem pengendalian intern pemerintah $\left(\mathrm{X}_{2}\right)$ sebesar 0,35 sehingga nilai signifikan lebih kecil dari 0,05 . Dengan demikian dapat disimpulkan bahwa sistem pengendalian intern pemerintah berpengaruh terhadap kualitas laporan keuangan pemerintah daerah di OPD Kabupaten Tegal.

3) Nilai signifikan t pemahaman basis akrual $\left(\mathrm{X}_{3}\right)$ sebesar0,000 sehingga nilai signifikan lebih kecil dari 0,05. Dengan demikian dapat disimpulkan bahwa pemahaman basis akrual berpengaruh terhadap kualitas laporan keuangan pemerintah daerah di OPD Kabupaten Tegal.

4) Nilai signifikan t pemanfaatan teknologi informasi $\left(\mathrm{X}_{4}\right)$ sebesar 0,03 sehingga nilai signifikan lebih kecil dari 0,05. Dengan demikian dapat disimpulkan bahwa pemanfaatan teknologi informasi berpengaruh terhadap kualitas laporan keuangan pemerintah daerah di OPD Kabupaten Tegal.

\section{Kesimpulan dan Saran}

5.1. Kesimpulan

1. Kompetensi SDM dengan nilai signifikan 0,004 lebih kecil dari 0,05 sehingga Kompetensi SDM berpengaruh terhadap kualitas laporan keuangan pemerintah daerah.

2. Sistem Pengendalian Intern Pemerintah dengan nilai signifikan 0,035 lebih kecil dari 0,05 sehingga Sistem Pengendalian Intern Pemerintah berpengaruh terhadap kualitas laporan keuangan pemerintah daerah.

3. Pemahaman Basis Akrual dengan nilai signifikan 0,000 lebih kecil dari 0,05 sehingga Pemahaman Basis Akrualberpengaruh terhadap kualitas laporan keuangan pemerintah daerah.

4. Pemanfaatan teknologi informasi dengan nilai signifikan 0,003 lbih kecil dari 0,05 sehingga Pemanfaatan teknologi informasi berpengaruh terhadap kualitas laporan keuangan pemerintah daerah.

5. Dari hasil uji koefisien determinasi, kualitas laporan keuangan pemerintah daerah dalam model ini dipengaruhi oleh variabel Kompetensi SDM, Sistem Pengendalian Internal Pemerintah dan 
Pemanfaatan Teknologi Informasi.

\subsection{Saran}

Berdasarkan beberapa kesimpulan yang telah diuraikan tersebut diatas, maka peneliti dapat memberikan saran-saran sebagai berikut:

1. Bagi OPD agar mengikut sertakan pegawai pada pendidikan dan pelatihan (diklat) mengenai bagaimana penyusunan laporan keuangan yang berlaku umum. Memberikan penghargaan/reward terhadap pegawai apabila pegawai memiliki kinerja yang memuaskan agar pegawai senantiasa memiliki komitmen dan loyal terhadap organisasi.

2. Pemahaman terkait sistem pengendalian intern dalam pemerintah daerah ditingkatkan lagi sesuai dengan apa yang diharapkan. Sistem pengedalian internal mampu memberikan kontribusi yang cukup dalam meningkatkan kualitas laporan keuangan. Dengan adanya penerapan sistem pengendalian yang baik, maka kualitas laporan keuangan pemerintah daerah kabupaten tegal semakin baik.

3. Semakin tinggi tingkat Pemahaman Basis Akrual maka kualitas informasi laporan keuangan pemerintah daerah Kabupaten Tegal akan semakin tinggi. Begitu pula sebaliknya, semakin rendah tingkat Pemahaman Basis Akrual maka kualitas informasi laporan keuangan pemerintah daerah Kabupaten Tegal akan semakin rendah. Jika standar akuntansi pemerintahan dapat diterapkan dengan baik dan selalu dipakai acuan dalam

\section{DAFTAR PUSTAKA}

Administrator. 2017. Untuk Pertama Kalinya, Pemkab. Tegal Raih Opini WTP BPK RI. Pemerintah Kabupaten Tegal Humas Sekretariat Daerah. Online. http://www.setda.tegalkab.go.id/2017/06/08/ untuk-pertama-kalinya-pemkab-tegal-raihopini-wtp-bpk-ri/. (31 Januari 2018).

Agung, M. T., \& Gayatri. 2018. “Analisis FaktorFaktor Yang Mempengaruhi kualitas Laporan Keuangan Pemerintah Daerah kabupaten Karangasem”. E-Jurnal Akuntansi Universitas Udayana. Vol 23. 2. 2018

Ahsani, Irvan. 2016. "Penerapan Standar Akuntansi Pemerintahan, Kompetensi Sumber Daya Manusia, dan Sistem Pengendalian Internal Serta Pengaruhnya Terhadap Kualitas penyusunan laporan keuangan maka pemerintah daerah akan memiliki kualitas informasi laporan keuangan yang baik dan benar. Dengan terciptanya laporan keuangan yang baik dan benar maka akan terwujud pemerintahan yang bersih dan berwibawa.

4. Pemerintah daerah berkewajiban untuk mengembangkan dan memanfaatkan kemajuan teknologi informasi untuk meningkatkan kemampuan mengelola keuangan daerah, dan menyalurkan informasi keuangan daerah kepada pelayanan publik (Peraturan Pemerintah No. 65 tahun 2010). Jika teknologi dimanfaatkan secara maksimal maka kualitas laporan keuangan pemerintah daerah semakin baik.

5. Berdasarkan hasil dari uji koefisien determinasi dengan hasil $66,3 \%$ hal tersebut menunjukan bahwa masih ada $33,7 \%$ yang dipengaruhi oleh variabel lain. Untuk peneliti selanjutnya diharapkan agar dapat menambahkan faktor-faktor lain seperti komitmen organisasi, gaya kepemimpinan dan efektivitas sistem informasi akuntansi yang dapat mempengaruhi kualitas laporan keuangan pemerintah daerah sehingga dapat dibandingkan dengan hasil penelitian peneliti. Penelitian ini dilakukan di organisasi perangkat daerah Kabupaten Tegal, disarankan agar peneliti selanjutnya memperluas atau memperbanyak jumlah responden atau objek yang diteliti.

Laporan Keuangan Satuan Kerja Perangkat Daerah (Studi Pada SKPD di Kabupaten Kotawaringin Barat, Kalimantan Tengah)". Universitas Muhammadiyah Yogyakarta. Skripsi. Program Studi Akuntansi. Universitas Muhammadiyah Yogyakarta.

Andrianto, Elvin. 2017. "Pengaruh Kapasitas Sumber Daya Manusia, Pemanfaatan Teknologi Informasi, dan Sistem Pengendalian Intern Pemerintah Terhadap Kualitas Laporan Keuangan Pemerintah Daerah Dengan Komitmen Organisasi Sebagai Variabel Moderasi (Studi Empiris Pada Satuan Kerja Perangkat Daerah di Kabupaten Sleman)". Universitas Negeri Yogyakarta. Skripsi. Program Studi Akuntansi. Universitas Negeri Yogyakarta.

Anisa, A.2017. Peran SKPD dalam Menghasilkan 
Laporan Keuangan Daerah yang Kredibel dan Akuntabel. Online. https://monitor.co.id/opini/peran-skpddalam-menghasilkan-laporan-keuangandaerah-yang-kredibel-dan-akuntabel/.

Desember 2018)

Artika, Y. 2016. "Pengaruh Penerapan Sistem Akuntansi Keuangan Pemerintah Daerah, Kapasitas Sumber Daya Manusia Dan Pemanfaatan Teknologi Informasi Terhadap Kualitas Laporan Keuangan Pemerintah Daerah Kabupaten Rokan Hulu (Studi Pada SKPD)". JOM Fekon Vol. 3 No. 1 (Februari), 219-233.

Armando, G. 2013. "Pengaruh Sistem Pengendalian Intern Pemerintah Dan PengawasanKeuangan Daerah Terhadap Nilai Informasi Laporan Keuangan Pemerintah (Studi Empiris pada Satuan Kerja Perangkat Daerah di Kota Bukittinggi)". Skripsi Akuntansi Fakultas Ekonomi Universitas Negeri Padang, Padang. Maret 2013.

Bastian, Indra. 2006. Akuntansi Sektor Publik: Suatu Pengantar.Jakarta: Erlangga.

BKD. 2018. Organisasi Perangkat Daerah (OPD) Kabupaten Tegal. 9 April 2018. Kabupaten Tegal.

BPK. 2018. Ikhtisar Hasil Pemeriksaan Semester (IHPS) I. BPK RI. Online. http://www.bpk.go.id/assets/files/ihps/2018/ I/ihps_i_2018_1507002855.pdf. (31 Januari 2018).

Elsye, R., Suwanda, D., \& Muchidin, U. 2016. Dasar-Dasar Akuntansi Akrual Pemerintah Daerah. Bogor: Ghalia Indonesia.

Faud, M. R. 2016. Analisis Laporan Keuangan Pemerintah Daerah. Bogor: Ghalia Indonesia.

Ghozali, I. 2018. Aplikasi Analisis Multivariate dengan Program IBM SPSS 25. Semarang: Badan Penerbit Universitas Diponegoro.

Halim, Abdul.2015. Auditing (Dasar-dasar Audit Laporan Keuangan).Jilid 1. Edisi kelima. Yogyakarta : UPP STIM YKPM.

Hamzah, A. P., \& Kustiani, N. A. 2014. Dasardasar akuntansi pemerintahanberbasis akrual,Tanggerang Selatan :Stan Press.
Manajemen.Yogyakarta : UPP STIM YKPN.

Indriasih, D., \& Koeswayo, P. S. 2014. "TheEffect Of GovermentApparatus Competence and the Effektivities Of Goverment Internal Control toward the Quality of Financial Reporting and its Impact on the Performance Accountability in Local Goverment". Research Journal of Financial and Accounting, 5 (20), 38-47

Isimiyati.2019. Potret Akuntabilitas Keuangan Daerah di Jawa Tengah. Online.http://www.bpkp.go.id/\%20jateng/ko nten/1912/Potret-Akuntabilitas-KeuanganDaerah-di-Jawa-Tengah.bpkp.(9 Februari 2019)

Juwita, R. 2013. "Pengaruh Implementasi Standar Akuntansi Pemerintah dan Sistem Informasi Akuntansi Terhadap Kualitas Laporan Keuangan ". Trinikom,Vol. 2No.2 Oktober, 201-2014.

Kartikasari, Dewi. 2012. “ Pengaruh Personal Blackground, Political Background, Pemahaman Regulasi Terhadap Peran Anggota Dprd Dalam Pengawasan Keuangan Daerah (Studi Kasus pada DPRD Kabupaten Boyolali). Jurusan Akuntansi. Universitas Negeri Semarang.

Kiranayanti, I. A., \& Erawati, N. M. 2016. "Pengaruh Sumber Daya Manusia, Sistem Pengendalian Intern, Pemahaman Basis Akrual Terhadap Kualitas Laporan Keuangan Daerah". E-Jurnal Akuntansi Universitas Udayana Vol.16.2. Agustus, 1290-1318.

Kadir, A. 2014. Pengenalan Sistem Informasi Edisi Revisi. Yogyakarta: Andi.

Karsana, I. W., \& Suaryana, I. G. 2017. "Pengaruh Efektivitas Penerapan SAP, Kompetensi SDM, Dan SPI Pada Kualitas Laporan Keuangan Pemerintah Kabupaten Bangli". E-Jurnal Akuntansi Universitas Udaya Vol.21.1. Oktober, 643-670.

Lamonisi, Sony. 2016. “Analisis Penerapan Standar Akuntansi Berbasis Akrual Pada Pemerintah Kota Tomohon" Jurnal EMBA 223 Vol.4 No.1 Maret 2016, Hal. 223-230.

Mardiasmo. 2009. Akuntansi Sektor Publik. Yogyakarta: Andi.

Meldona. 2009. Manajemen Sumber Daya Manusia 
Perspektif Integratif. Malang: UIN-Malang Press (Anggota IKAPI).

Muluk, K. 2006. Desentralisasi dan Pemerintahan Daerah. Malang: Bayumedia Publising dan Center for Indonesian Reform.

Munawir. 2014.Analisa Laporan Keuangan.Edisi 4. Yogyakarta : Liberty.

Nurillah, As Syifa. 2014. "Pengaruh Kompetensi Sumber Daya Manusia, Penerapan Sistem Akuntansi Keuangan Daerah, Pemanfaatan Teknologi Informasi, Dan Sistem Pengendalian Internal Terhadap Kualitas Laporan Keuangan Daerah (Studi Empiris Pada SKPD Kota Depok)". Skripsi akuntansi Fakultas Ekonomika dan BisnisUniversitas diponegoro, Semarang. 19 Maret 2014.

Pradono, C. F., \& Basukianto.2015. "Kualitas Laporan Keuangan Pemerintah Daerah : Faktor Yang Mempengaruhi Dan ImplikasiKebijakan (Studi Pada SKPD Provinsi Jawa Tengah). Jurnal Bisnis Dan Ekonomi (JBE), September 2015, Hal. 188200.

Rachmawati, K. I. 2008. Manajemen Sumber Daya Manusia. Yogyakarta:

CV Andi Ofset.

Rahmadani, S. 2015. "Pengaruh Kompetensi Sumber Daya Manusia, Sistem Akuntansi Keuangan Daerah, Pemanfaatan Teknologi Informasi Dan Sistem Pengendalian Intern Terhadap Kualitas Laporan Keuangan Pemerintah Daerah (Studi Pada SKPD Kab. Pasaman Barat)". JOM Fekon Vol.2 No.2 Oktober, 1-15.

Rahman, D. 2015. "Pengaruh Pemanfaatan Teknologi Informasi, Penerapan Sistem Akuntansi Keuangan Daerah, Dan Penerapan Standar Akuntansi Pemerintahan Terhadap Kualitas Laporan Keuangan Daerah (Studi Empiris Pada SKPD Provinsi Riau)". JOM Fekon Vol.2 No.2 Oktober, 115.

Republik Indonesia. Peraturan Pemerintah Nomor 71 Tahun 2010 Tentang Standar Akuntansi Pemerintahan.

Republik Indonesia 2008. Undang-Undang Nomor 60Tahun 2008 Tentang Sistem Pengendalian Intern.
8Tahun 2006 Tentang Sistem Pengendalian Intern.

Republik Indonesia. Peraturan Pemerintah Nomor 65 Tahun 2010 Tentang Perubahan Atas Peraturan Pemerintah Nomor 56 Tahun 2005 Tentang Sistem Informasi Keuangan Daerah.

Republik Indonesia. Peraturan Menteri Dalam Negri Nomor 13 Tahun 2006 tentang Pedoman Pengelolaan Keuangan Daerah.

Reza,A.2018. Pemkab Tegal Kembali Raih Opini WTP dari BPK.Online.https://kumparan.com/panturapost/pe mkab-tegal-kembali-raih-opini-wtp-dari-bpk. (25 Desember 2018).

Rosalin, Faristina. 2011. "Faktor-Faktor Yang Mempengaruhi Keandalan Dan Timeliness Pelaporan Keuangan Badan Layanan Umum (Studi pada BLU di Kota Semarang)". Universitas Diponegoro Semarang. Skripsi. Program Studi Akuntansi. Universitas Diponegoro Semarang.

Rusdiana, A\& Irfan, Moch. 2014. Sistem Informasi Manajemen. : Bandung: CV PUSTAKA SETIA.

Saputra, A. 2015. "Pengaruh Penerapan Standar Akuntansi Pemerintahan, Sistem Pengendalian Intern Dan Kompetensi Sumber Daya Manusia Terhadap Kualitas Laporan Keuangan (Studi Pada SKPD Kabupaten Kampar)". JOM Fekon Vo.2 No.2 Oktober, 1-15.

Sari, N. 2016. "Pengaruh Kapasitas Sumber Daya Manusia, Pemahaman Akuntansi, Penerapan SAP, Pemanfaatan Teknologi Informasi, Dan Sistem Pengendalian Intern Terhadap Kualitas Laporan Keuangan Pemerintah Daerah (Studi Empiris Pada SKPD Kabupaten Bungo)". JOM Fekon Vol. 3 No. 1 (Februari), 1478-1490.

Simamor, Hendry. 2001. Manajemen Sumber daya manusia. Edisi 2. Yogyakarta :STIE YKPN.

Siska \& Sari, R. D. 2016. "Pengaruh Penyajian Laporan KeuanganDaerah, Sumber Daya Manusia (SDM), Pengendalian Internal, dan AksesibilitasTerhadap Penggunaan Laporan KeuanganDaerah pada SKPDdi Kabupaten Indragiri Hulu". Jurnal Ekonomi KIAT I Vol. 26 No. 1 Juni 2016

Republik Indonesia 2006. Undang-Undang Nomor 
Subramanyam, K.R. \& Wild, J.J. 2016. Analisis Laporan Keuangan. Jakarta:Salemba Empat.

Sugiyono. 2017. Metode Penelitian Pendidikan.Bandung:Alfabeta

Sugiyono. 2017. Statistika untuk penelitian. Bandung:Alfabeta

Sujarweni. 2015. Akuntansi Sektor Publik.Yogyakarta:Pustaka Baru Press.

Supriyadi, B., Suwanda, D., \& Manghayu, A. 2017. Kebijakan Akuntansi Akrual Pemerintah Daerah. Bogor: Ghalia Indonesia.

Sutrisno, Edy. 2016. Manajemen Sumber Daya Manusia.Jakarta:Prenadamedia Group

Sunyoto, Danang. 2013. Metode Penelitian Akuntansi. Bandung:PT. Refika Aditama.

Triwardana, D. 2017. "Pengaruh Penerapan Standar Akuntansi Pemerintahan, Penerapan Sistem Akuntansi Keuangan Daerah, Dan Kompetensi Sumber Daya Manusia Terhadap Kualitas Laporan Keuangan SKPD (Studi Pada Pemerintah Daerah Kabupaten Kampar)". JOM Fekon Vol. 4 No. 1 (Februari), 641-655.

Turwirdani, L . 2015. "Pengaruh Sistem Pengendalian Intern Pemerintah, Kompetensi Sumber Daya Manusa, Sistem Akuntansi Keuangan Daerah, dan Pengawasan Fungsional Tehadap Efektivitas Pengelolaan Keuangan Daerah (Studi Pada Satuan Kerja Perangkat Daerah Kota Pariaman)".Jom Fekon Vol. 2 No. 2 Oktober 2015

Yosefrinaldi. 2013. Pengaruh Kapasitas Sumber Daya Manusia Dan Pemanfaatan Teknologi Informasi Terhadap Kualitas Laporan Keuangan Pemerintah Daerah Dengan Variabel Intervening Sistem Pengendalian Intern Pemerintah (Studi Empiris Pada Dinas Pengelolaan Keuangan Dan Aset Daerah Se-Sumatera Barat). Vol.1,No.1.

Yuliani, N., Nadirsyah, \& Bakar, U. 2010. "Pengaruh Pemahaman Akuntansi, Pemanfaatan Sistem Informasi Akuntansi Keuangan Dan Peran Internal Audit Terhadap Kualitas Keuangan Daerah (Studi pada Pemeritah Banda Aceh”. Jurnal Telaah dan Riset Akuntansi Vol. 3. No. 2. Juli 2010 